\title{
$\mathbf{X}$ 線回折法による 2 次元検出器を用いた 薄膜材料の極点図測定・残留応力測定
}

\author{
長 尾 圭 悟 ${ }^{\mathrm{a}}$
}

a(件リガク 応用技術センター（～１96-8666＼cjkstart東京都昭島市松原町 3-9-12)

\section{Pole Figure and Residual Stress Measurement of Thin Film Materials \\ by X-Ray Diffraction Method Using a Two-Dimensional Detector}

\section{Keigo NAGAO ${ }^{\text {a }}$}

${ }^{a}$ Rigaku Corporation(3-9-12, Matsubara-cho, Akishima-shi, Tokyo 196-8666)

\section{1.はじめに}

X 線回折法は, ブラッグの回折条件を基にして結晶構造情 報を得るための重要な手段として様々な分野・材料に用いら れており，その歴史も長い。元素分析である蛍光 $\mathrm{X}$ 線分析 法と比較して，X線回折法の定性分析は元素ではなく「化合 物」として同定できるという利点がある。

実験室系の X 線回折装置で用いられるターゲットとして は， $\mathrm{Cu}$ をはじめ, $\mathrm{Cr}, \mathrm{Co}, \mathrm{Mo}$ などが用いられる。試料表 面からの侵入深さは, 使用する波長や入射角, 試料の線吸収 係数によって異なるが, おおよそ数 $\mu \mathrm{m}$ ～数十 $\mu \mathrm{m}$ であり, 試料の表面近傍の情報を得ることができる。めっき膜をはじ めとする薄膜材料の膜厚は数十 $\mathrm{nm}$ から数 $\mu \mathrm{m}$ のオーダーが 多いこと，また， X 線照射野としては数十 $\mu \mathrm{m}$ から十数 $\mathrm{mm}$ であることから, 電子顕微鏡と比較するとX 線回折法は薄 膜材料の巨視的な評価に適していると言える。

薄膜材料, 特にめっき膜では, 膜の結晶方位と配向の強さ, 結晶粒径, また内部応力 (残留応力)によって機能性, 密着性 等の材料特性に大きな影響を及ぼす ${ }^{1), 2)}$ 。結晶方位や残留応 力を $\mathrm{X}$ 線回折装置で評価する際, シンチレーションカウン 夕などの 0 次元検出器や半導体素子が搭載された 1 次元検出 器が従来使用されてきた。しかし，ここ最近では実験室系の 装置でも，デバイリングを直接観測できる 2 次元検出器も一 般的になりつつある。

本稿では, $\mathrm{Zn}$ めっき膜を試料として, 2 次元検出器を用 いた極点図測定・結晶方位解析と残留応力測定について解説 する。また, 従来行われてきた 0 次元測定と比較し, 2 次元 での測定の長所・短所についても言及する。

\section{2 次元検出器の特徵}

図 1 に 2 次元検出器を搭載した装置概観を示す。検出面上 にはピクセルと呼ばれる微細な検出素子が縦・横方向に並ん
でおり，デバイリング(回折像)を取得する 2 次元測定を行う 際はソーラースリットや受光スリットなどは取り外し, 受光 側は検出器のみにする。

2 次元検出器の長所として以下が挙げられる。

(1) 配向の有無や粗大粒が一目で把握可能。

(2) $2 \theta$ 方向とあおり $(\beta)$ 方向の情報が同時に得られる。

(3) 試料と検出面間の距離(カメラ長)を変更することができ, 一度に取得できる $2 \theta$ 範囲やあおり方向の範囲を広げる ことができる。

(4) 半導体素子を搭載した 2 次元検出器では走査しながら測 定できるため, 画像のつなぎ合わせをせずに広い $2 \theta$ 範 囲の 2 次元回折像を取得できる。

(5) 検出器を固定して測定する露光方式の場合は, 短時間で 多量の画像を取得できるため, 温調などの in-situ 測定に おいて, 試料の速い相変化を追随して観測することがで きる。

また，短所としては以下が挙げられる。

(1) 正しい回折像を得るためには, 試料上でX 線をポイン ト状にして照射する必要があり, 微小部測定用の光学系 となる。試料上に広く照射されるライン線源に対し，回

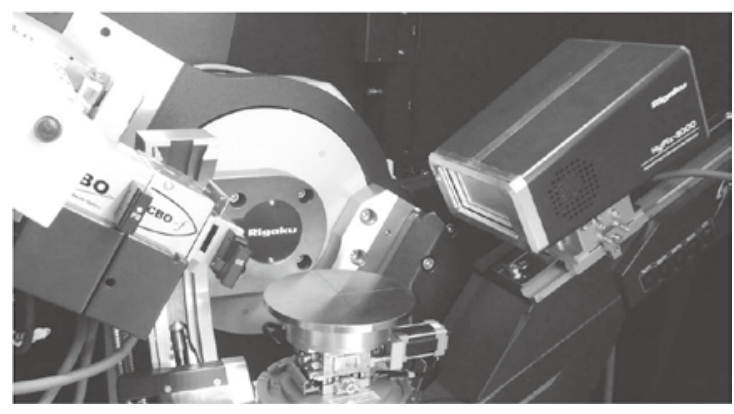

図 1 試料水平ゴニオメー夕に 2 次元検出器を搭載した $\mathrm{X}$ 線回折装置概観 
折に寄与する格子面が少ないため, 粗大粒の影響を受け やすい。

(2)受光側にスリット類が無いために, 試料上での X 線照 射幅が角度分解能に直結する。集中法など従来のライン 線源よりも角度分解能が劣る場合が多い。

図 2 に標準的な作製条件での $\mathrm{Zn}$ めっき膜 (a) と作製条件を 変更した $\mathrm{Zn}$ めっき膜(b)の 2 次元回折像を示す。 $2 \theta=30$ か ら $90^{\circ}$ までを $10^{\circ} /$ 分で $2 \theta / \theta$ 測定を行った。デバイリングの周 方向(あおり方向)の強度分布は, 試料表面に対し傾いた格子 面の情報を表しており，標準めっき試料と作製条件変更試料 (2)では回折線の観測位置は同じだが，あおり方向の強度変化 が異なることから配向状態が異なることが一目で分かる。

\section{2 次元回折像を用いた簡易方位解析}

図 2 の 2 次元画像の赤道部分付近のみを 1 次元プロファイ ル $(2 \theta$-強度)に変換し，定性分析を行った結果を図 3 に示す。 めっき膜の厚みが約 $3 \mu \mathrm{m}$ で, 入射 $\mathrm{X}$ 線が基板である鋼板 に到達するため $\alpha$-Fe の回折線も観測される。1 次元プロファ イルから，どの格子面が試料表面と平行であるか，また，そ の配向の程度(強さ)を解析するには, ランダムな強度比を表 すデータベース (もしくは粉末試料の実測データ)の相対強度 を用いて，各指数の実測の強度比を規格化する手法がよく用 いられる ${ }^{3)}$ 。規格化された各指数の值の内, 1.0 よりも高い 值を示した指数が試料表面と平行に集積していることになる。

図 2 のような 2 次元回折像から結晶方位を解析するには, あおり方向の強度情報も同時に得られるという利点を生かし， $\beta$ 方向の強度分布 $(\beta$ プロファイル)を用いる。図 4 に各指数 のデバイリングに沿った $\beta$ プロファイルを示す。 $\beta=180^{\circ}$ の 位置が図 2 の 2 次元回折像の赤道部分に相当し, 試料表面と

(a)

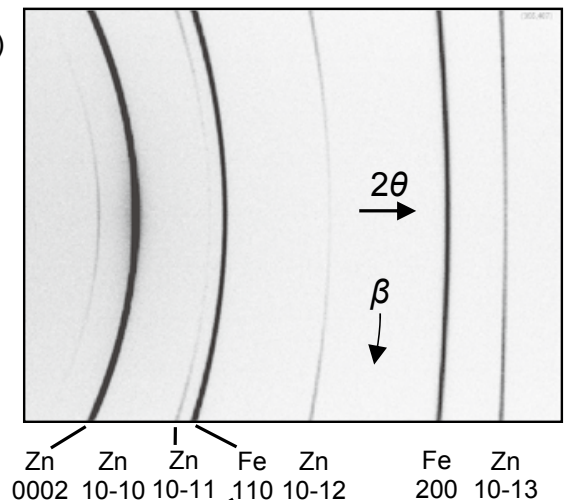

(b)

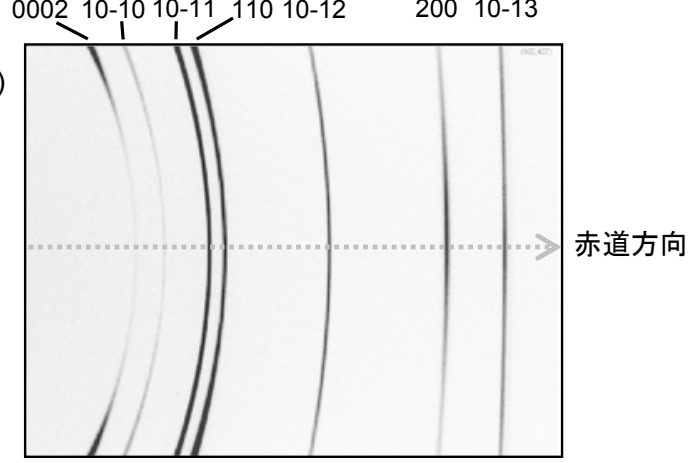

図 $2 \mathrm{Zn}$ 標準めっき試料(a) と作製条件変更試料(2)(b)の 2 次元回折像
平行な格子面の情報が得られる。 $\beta$ の值が $180^{\circ}$ から離れるほ ど，試料表面に対し傾いた格子面の情報を表す。標準めっき 試料では Zn 0002 の $\beta$ プロファイルのピーク位置が $180^{\circ}$ に位 置していることから，(0002)面が試料表面と平行であること が分かる。また, そのピークの半值幅から配向の程度を知る ことができる。 0 次元検出器の場合は, 各指数の $2 \theta$ 位置に ゴニオメータを固定し, 入射角 $(\omega)$ を変化させたプロファイ ル (ロッキングカーブプロファイル)から半值幅を得ていた。 2 次元検出器を用いれば $10^{\circ} /$ 分程度のスキャン 1 回のみで 解析が可能であり, 0 次元に比べて格段に短い時間で評価を 行うことができる。

作製条件変更試料(2)の $\beta$ プロファイルにおいて， $\beta=180^{\circ}$

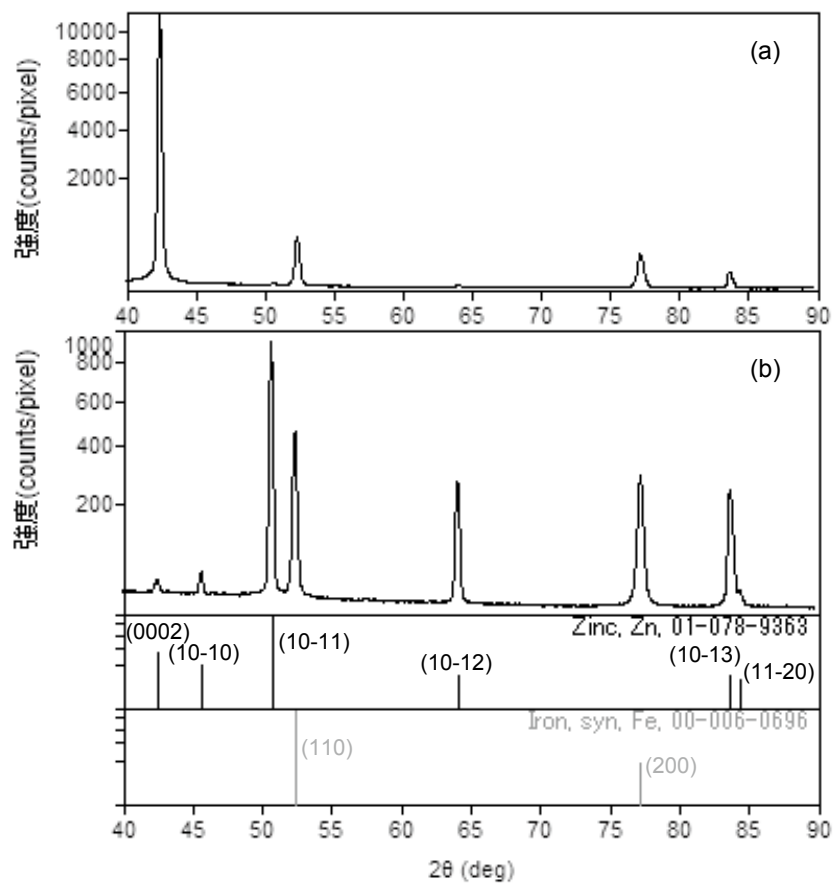

図 $3 \mathrm{Zn}$ 標準めっき試料 (a) と作製条件変更試料(2)(b)の 定性分析結果と各指数間の相対強度比較

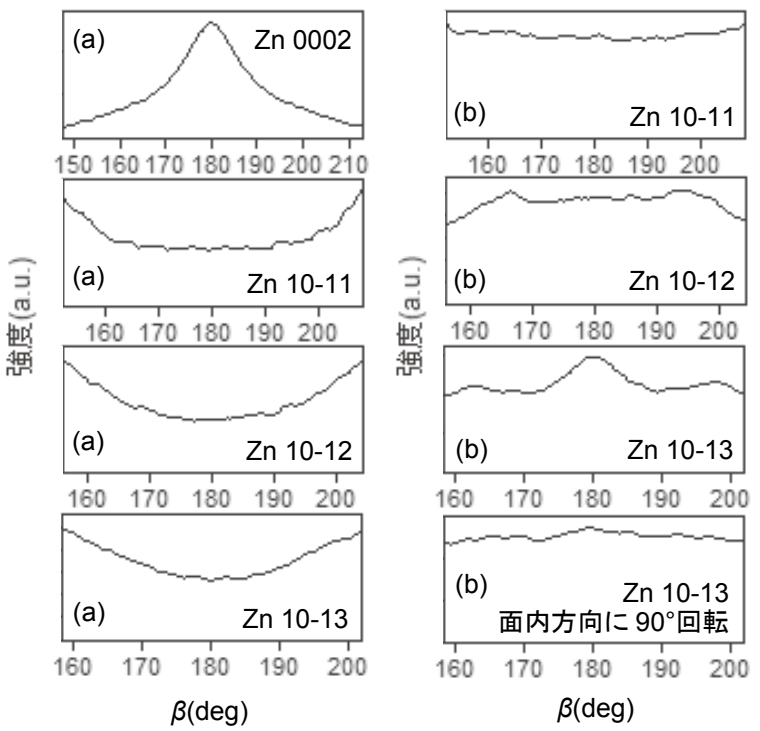

図 $4 \mathrm{Zn}$ 標準めっき試料 (a) と作製条件変更試料(2) (b)の 各指数の $\beta$ プロファイル 
の位置にピークがある指数は 10-13 であるが，(10-12) 面も試 料表面に対しほぼ平行に位置している格子面と推測される。 このことから作製条件変更試料(2)の結晶方位は，ある単一の 指数で表すことはできず，複数の優先方位があり，分布が存 在すると推測される。また, 面内方向に $90^{\circ}$ 回転させた 10-13 の $\beta$ プロファイルを見るとその形状が異なっており， 面内方向に異方性があることが分かる。より詳細に結晶方位 を評価するには次章の極点図測定が適している。

\section{2 次元検出器による極点図測定}

0 次元検出器による極点図測定法としてシュルツ反射法が ある。測定としては，ある指数の $2 \theta$ 位置にゴニオメータを 固定し，固定したあ扔り角の位置で面内方向に試料を回転さ せ， 5 ステップ程度で強度分布を取得する。終了後, あおり 角を $5^{\circ}$ 程度ずらし，その位置で面内方向の強度分布を取得， という操作を繰り返す。通常, あおり角は 0 から $75^{\circ}$ までを 測定する。

一方，図 5 (a) は作製条件変更試料(2)をあおり角 $30^{\circ}$ にて 露光時間 5 秒で測定した 2 次元回折像である。この場合，あ おり角 $60^{\circ}$ 分の情報を同時に得ることができる。図 5 (a)の 各指数にある枠は極点図への取り込々範囲を示している。上 記を踏まえて，2 次元検出器による極点図測定の長所は以下 が挙げられる。

（1）あ抢り角を段階的に変化させて測定する必要はなく，一 つのあ扮り角にて面内方向に試料を回して $5^{\circ}$ ステップ 程度で画像を取得していくだけで極点図を作成するため のデータが得られる。72枚の画像が必要になるが, 画 像 1 枚の露光時間は 5 秒なので, ゴニオメータや軸の移 動を加味しない測定時間は 6 分とかなりの高速で測定で きる。

(2) 検出面に観測された複数の指数の極点図を 1 回の測定で 同時に作成できる。図 5 (a)の場合，Zn 0002，10-10， 10-11 の極点図が同時に得られる。
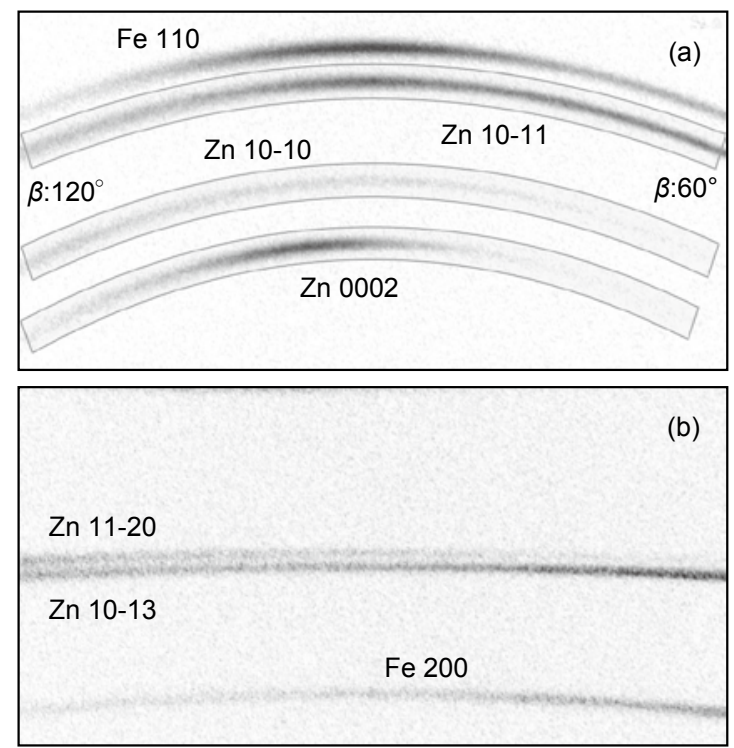

図 5

(a) 2 次元回折像から複数極点図の同時作成 (b) 近接した回折線存在下での極点図の作成
（3）シュルツ反射法では, 回折線による強度が検出されない バックグラウンド位置にゴニオメータを移動し, 各々の あ㧍り角でバックグラウンド測定を行う必要がある。一 方，2 次元回折像ではバックグラウンド位置の強度も同 時に得られるため, バックグラウンド測定は必要ない。

（4）Zn10-13 の極点図を作成する場合, 図 5 (b)に示すよう にZn11-20 がかなり近接した位置に存在している。0 次 元測定によるシュルッ反射法では, 受光スリットの幅を 調節して, Zn 11-20 の信号が取り込まれない $2 \theta$ 範囲を 決定する。ただ，受光スリット幅の設定に誤りがあった 場合, 再度測定する必要がある。2 次元回折像の場合, 再測定は必要なく, 極点図を作成するための切り出し範 囲を再設定するだけでよい。また，近接した反射が存在 するという記録を残すことができる。

2 次元検出器の極点図測定の短所としては下記が挙げられる。

(1)極点図の中心部は, 試料表面と平行な格子面の情報を表 している。特別な計算を行わずに極点図中心部の情報を 得るためには対称配置 ( $2 \theta / \theta$ 配置) で着目する指数の回折 像が検出面の中心に観測されるように設定する必要があ る。従って, 極点図の中心部分を得るためには 1 指数ず つ $2 \theta$ 位置を変更して測定を行う必要がある。

(2)一つのあおり角による測定だけでは極点図中で得られる $\alpha$ 範囲が 0 次元によるシュルッ反射法に比べて狭い。ま た, 得られる $\alpha$ 範囲は $2 \theta$ 位置, 入射角, あ抢り角, カメ ラ長によって変化する。

(3) 試料の吸収による影響で，ランダムな粉末を測定しても, 2 次元回折像中のデバイリングの端と端で強度差は数倍 になる。正しい強度を持った極点図を得るには，ランダ 厶粉末もしくは 2 次元画像上での吸収補正による強度補 正が必要である。異なるあおり角で測定した極点図を結 合する際は注意を要する。

(4) 微小部用の光学系で測定するため, 粗大粒の影響を受け やすく，極点図上にスポットが検出される場合がある。 粗大粒の影響は $\omega$ 摇動と $\chi$ 摇動で抑制できる。

あおり角 $30^{\circ} に お け る$ 作製条件変更試料(2)の 2 次元検出器 による極点図を図 6 に示す。Zn10-13 の極点図作成において，

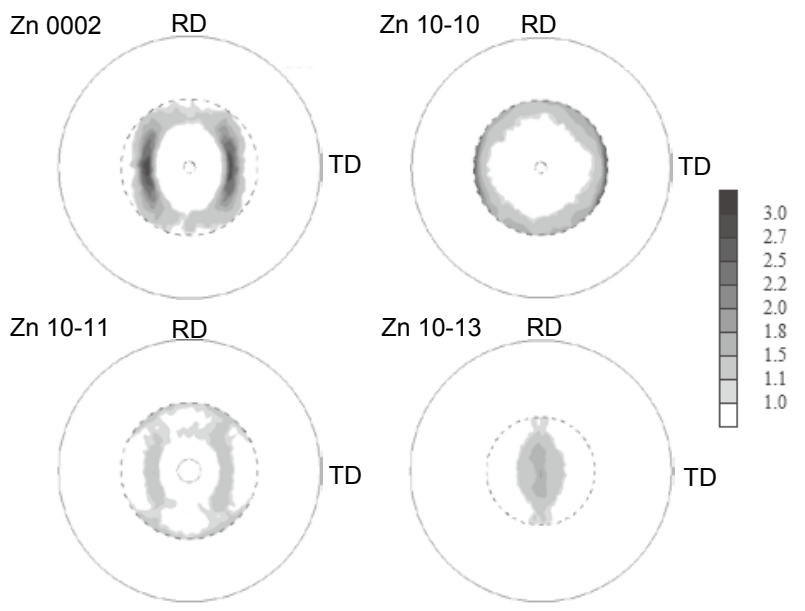

図 6 作製条件変更試料(2) Zn 0002，10-10，10-11，10-13 の測 定極点図 
あおり角 $0^{\circ}$ と $30^{\circ}$ で測定し, 各々のあおり角での極点図を結 合した。破線の範囲内が得られた $\alpha$ 範囲である。Zn 10-13の 極は RD と定義した方向に伸びていることが分かる。得られ た極点図だけを用いての結晶方位の解析には限界があるため, 次章の結晶方位分布解析 (ODF) が有効である。

\section{ODF 解析による全極点図と逆極点図の作成}

ODF (Orientation Distribution Function)では，試料軸 (RD, $\mathrm{TD}, \mathrm{ND})$ と結晶軸の角度差である Euler 角 $\left(\phi_{1}, \Phi, \phi_{2}\right)$ から 解析する ${ }^{4)}$ 。この $\phi_{1}, \Phi, \phi_{2}$ を 3 軸に取り, 3 次元的な極密 度分布を描くと図 7 のようなオイラー空間が得られる。通常 は $\phi 2$ 方向の断面図で表すことが多く, 結晶方位分布図と呼 ばれる。この結晶方位分布図から下記の解析が可能である。

(1) 優先方位 $\{\mathrm{hkl}\}<\mathrm{uvw}>$ の特定

(2) 任意の指数の全極点図の再計算

(3) 逆極点図の作成

(4) 複数の優先方位間における体積分率の算出 ${ }^{5)}$

今回は上記の解析の内，全極点図の再計算と逆極点図の作 成を行った(図 8)。単一のあおり角にて 2 次元検出器を用い て得られた極点図の $\alpha$ 範囲は広くはないため, 複数の極点図 から ODF 解析により極点図の中心部を含む全極点図を作成 できることは非常に有効である。ND 方向の逆極点図からは 試料表面に平行な格子面の情報が得られる。3 章でも, ラン ダムな相対強度を用いての試料表面と平行な格子面の評価法 について触れたが，実際に観測される指数のみでの評価にな るため, 試料表面と平行な格子面が観測されない指数である 場合は正確な評価が困難である。結晶方位分布図から計算さ れる逆極点図では任意の指数を考慮するため, 多くの情報を 有している。図 8 (b)から，(10-13)の他に(22-49)付近の格子 面が試料表面と平行であることが分かる。

\section{2 次元検出器による残留応力測定}

汎用機による残留応力測定では従来, 0 次元検出器の前に PSA（Parallel Slit Analyzer）を設置した光学系で測定する。 Parallel Slit Analyzer は特定の角度の回折 X 線のみを通過させ るため, 試料表面が湾曲している，もしくは偏心がある場合 でもピーク位置はシフトしない。X線回折による残留応力測

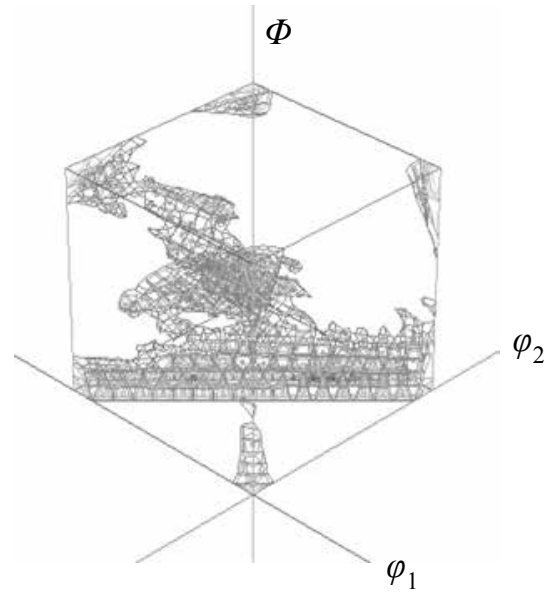

図 7 極密度分布の 3 次元的表示 (立方晶)

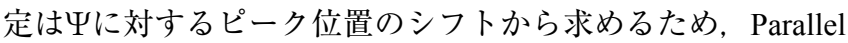
Slit Analyzer は正確な残留応力值を求めるために非常に有効 である。しかし，0 次元測定であるため, 強度が低い高角度 側の回折線を測定するには長時間を要する場合がある。図 9 に 0 次元検出器と 2 次元検出器での強度比較を行ったプロ ファイルを示す。入射側は試料上でポイント状に集光する光 学系であり, 両検出器で全く変更していない。2 次元検出器 の場合は残留応力測定でよく設定されるカメラ長 $200 \mathrm{~mm}$ で 行い, 0 次元検出器の場合は $300 \mathrm{~mm}$ で測定した。両検出器 で測定所要時間を揃えた結果が $(a)$ と (b)である。2 次元検出

(a)
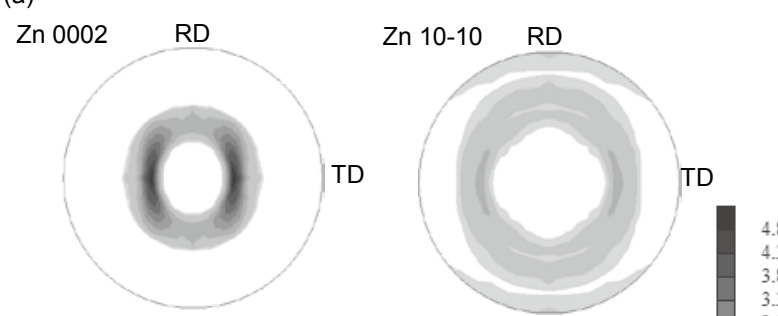

Zn 10-11 RD

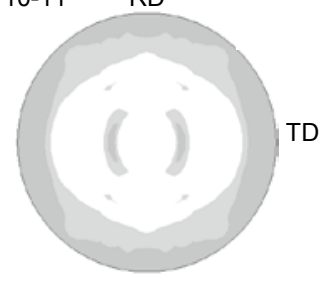

Zn 10-13 R
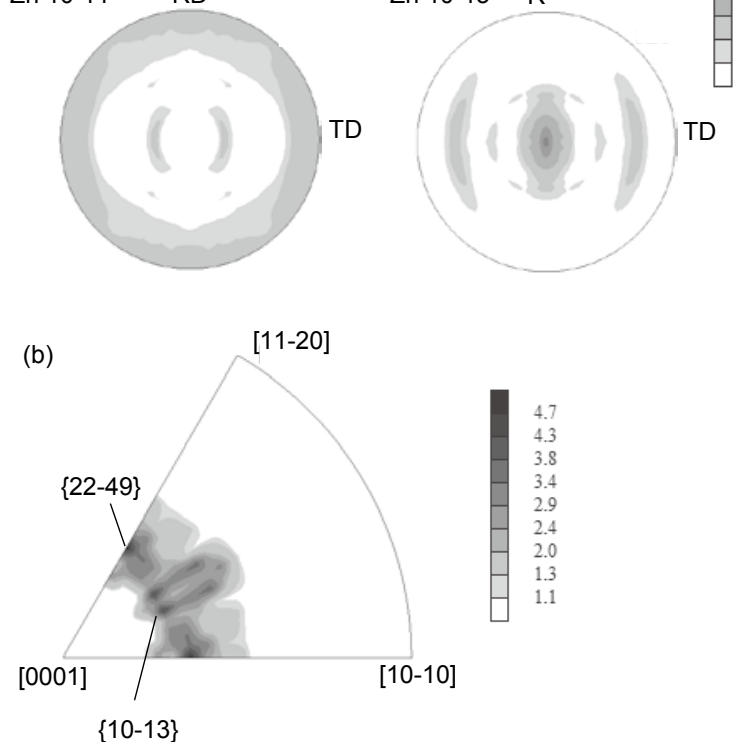

図 8 (a) ODF 解析による作製条件変更試料(2) Zn 0002，10-10, 10-11，10-13 の再計算全極点図 (b) 逆極点図 $(\mathrm{ND})$
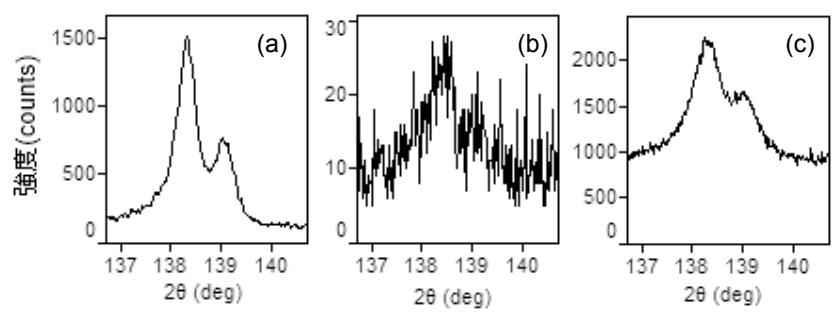

図 9 PSA (Parallel Slit Analyzer) $0.5^{\circ}$ を用いた 0 次元測定と 2 次元 露光測定の強度比較 (試料 : セラミックキャパシタ)

(a) 2 次元露光測定 (露光時間 : 1 分, $\beta: 20^{\circ}$ 分を 1 次元 プロファイルに変換)

(b) 0 次元測定 (スキャン速度 : $4^{\circ} /$ 分, 測定所要時間 : 1 分)

(c) 0 次元測定 (スキャン速度 : $0.04^{\circ} /$ 分, 測定所要時間 : 100 分) 
器の場合は露光時間 1 分でも解析を十分に行える強度が得ら れた。2 次元検出器と同等のピーク強度を 0 次元検出器で得 るためには 100 分を要した (c)。この強度差は, カメラ長の 違いもあるが, 2 次元検出器は露光方式で測定しており, 測 定している全角度範囲の強度が同時に積算されること，また， 得られたデバイリングの周方向 $20^{\circ}$ 分を 1 次元プロファイル に変換している点が高強度化に寄与していると考えられる $(0$ 次元検出器の周方向の取込み範囲は約 $\left.5^{\circ}\right)$ 。

0 次元検出器による測定と比較した, 2 次元検出器を用い た残留応力測定における長所は下記が挙げられる。

(1) 上記の説明のように検出器を $2 \theta$ 方向にスキャンする必 要がないため 0 次元検出器に比べて圧倒的に短時間で測 定可能。

（2）あおり方向の情報も得られるため，粗大粒や配向(集合 組織)を有する試料に対し, 0 次元に比べて残留応力值 の偏差が小さい, 質の高いデータが得られる。

(3) 露光方式で測定するため, 入射角 $(\omega)$ を摇動することが でき，回折に寄与する格子面を増やすことにより粗大粒 や配向の影響を軽減することができる(あおり方向の試 料摇動は 0 次元 $\cdot 2$ 次元両方で可能)。

欠点としては下記が挙げられる。

(1) 0 次元測定時のように検出器の前にPSA が無いため, 偏心誤差が存在する。従って, 並傾法の場合は $\omega$ 方向に

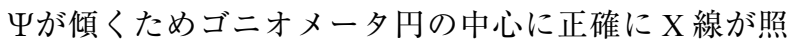
射される必要がある。側傾法の場合は，試料があおり方 向に傾くため，あおり軸の回転中心にX 線が照射され る必要がある。光学系のアライメント状態を確かめるた めに, 残留応力が存在しない粉末試料を測定し, 誤差の 範囲内で残留応力值が $0 \mathrm{MPa}$ であることを確認する必 要がある。

(2) 前述したように受光側にスリット類が無いため, 試料上 のX線照射野がそのまま角度分解能に直結する。低角 度(おおよそ $20^{\circ}$ 以下)で $X$ 線を入射した場合，ピーク幅 が広がり，ピーク位置 $(2 \theta)$ を決定する精度が落ちる。

表 1 に配向状態が異なる無光沢 Zn めっき膜の残留応力測 定結果を示す。測定・解析は従来の $\sin ^{2} \Psi$ 法ではなく2D 応 力法を用いた。 $2 \mathrm{D}$ 応力法は，1つの指数のデバイリングの 歪から残留応力を求める手法で ${ }^{6}$, 面内方向に直交する応力 成分 $\sigma_{11}, \sigma_{22}$ とせん断応力である $\sigma_{12}$ が同時に得られる。測 定法としては $\sin ^{2} \Psi$ 法と似ており, 面内方向 $(\phi)$ に $45^{\circ}$ ステッ
プで 4 点測定し, 各 $\phi$ 位置で $\Psi$ 変えて 4 点, 計 16 枚の回折 像を取得した。露光時間は，4〜10 分とした。測定後，2次 元データ上のデバイリングを分割し，各々の箇所における 2 $\theta$ 位置をプロファイルフィッティングで求め, 歪を解析する。 $\beta$ プロファイルを用いた手法により作製条件変更試料(1), (3) についても配向状態を評価し, 表 1 に記した。測定に使用し た指数が 0002 であっても，配向状態は 0001 配向と記した。 標準めっきでは 0001 配向であり僅かな圧縮応力であるが, 配向状態が異なると, 作製条件変更試料(1)では圧縮応力が高 く観測され，また，作製条件変更試料(3)では圧縮から引張り に僅かに転じていることが分かる。また, 誤差の範囲内でど の試料もせん断応力は無いと言える。

表 2 に, 光沢材の投入量を変化させた場合の $\mathrm{Zn}$ めっき膜 の残留応力值と結晶子サイズ・格子歪を示す。ここでの格子 歪 $(e)$ は, $e=\delta d / d$ で表され, 結晶の不均一歪みを指す。結 晶子サイズを正確に求めたい場合は, 回折線幅が広がるもう 1 つの要因である格子歪も併せて解析したほうがよい。格子 歪が存在するかどうかは複数試料の低角度側と高角度側の回 折線幅に着目し, 高角度側で回折線幅が増大しているかで判 断できる。今回は, 集中法 (Bragg-Brentano) 光学系にて 1 次 元測定で広い $2 \theta$ 範囲のプロファイルを取得し, WPPF (Whole Powder Pattern Fitting) 解析により值を算出した。光沢材の投 入量が増えると圧縮の残留応力が高くなり, 結晶子サイズは 小さくなっていることが分かる。これは, 結晶粒が微細化す ると内部応力が増加すると考えられる。なお, 表 1 の標準めっ きの結晶子サイズは $100 \mathrm{~nm}$ を超えるため絶対值としては評 価できないが，結晶子を球形として解析すると $285 \mathrm{~nm}$ であ り，格子歪は $0.01 \%$ 以下であった。

図 10 に平板試料を直角に折り曲げた試料を示す。試料観 察カメラを用いて，その折り曲げ部付近にのみにポイント状 の X線を照射して，折り曲げによる影響を調べた。このよ うな特定の箇所を狙う測定では微小点測定になるため, 0 次

表 2 光沢材投入量を変化させた場合の残留応力値と結晶子サ イズ・格子歪

\begin{tabular}{cccc}
\hline $\begin{array}{c}\text { 光沢材 } \\
\text { 投入量 }\end{array}$ & $\begin{array}{c}\text { 残留応力值 } \\
(\mathrm{MPa})\end{array}$ & $\begin{array}{c}\text { 結晶子サイズ } \\
(\mathrm{nm})\end{array}$ & $\begin{array}{c}\text { 格子歪 } \\
(\%)\end{array}$ \\
\hline $1 / 6 *$ & $-9.1 \pm 2.6$ & 121 & 0.10 \\
$1 / 2 *$ & $-8.1 \pm 3.9$ & 86.8 & 0.19 \\
標準量 & $-59.0 \pm 10.6$ & 70.3 & 0.24 \\
1.5 倍* & $-63.7 \pm 13.3$ & 69.4 & 0.20 \\
\hline
\end{tabular}

* 標準量に対しての相対的な投入量を表す

表 1 配向状態が異なる試料の 2D 応力法による Zn めっき膜の残留応力解析結果

\begin{tabular}{|c|c|c|}
\hline 測定試料 & 残留応力値 (MPa) & 配向状態 \\
\hline 標準めっき & $\begin{array}{r}\sigma_{11}:-2.5 \pm 2.8 \\
\sigma_{22}:-4.9 \pm 2.8 \\
\sigma_{12}: \quad 2.4 \pm 1.0\end{array}$ & 0001 配向 \\
\hline $\begin{array}{l}\text { 作製条件 } \\
\text { 変更試料(1) }\end{array}$ & $\begin{aligned} & \sigma_{11}:-19.5 \pm 1.9 \\
& \sigma_{22}:-25.2 \pm 1.9 \\
& \sigma_{12}: 0.8 \pm 0.7\end{aligned}$ & $\begin{array}{l}0001 \text { 配向 } \\
\text { 10-10 配向 }\end{array}$ \\
\hline $\begin{array}{l}\text { 作製条件 } \\
\text { 変更試料(2) }\end{array}$ & $\begin{array}{r}\sigma_{11}:-5.5 \pm 0.9 \\
\sigma_{22}:-3.7 \pm 0.9 \\
\sigma_{12}:-0.3 \pm 0.6\end{array}$ & $\begin{array}{l}\text { 10-13 配向 } \\
\text { 22-49 配向 }\end{array}$ \\
\hline $\begin{array}{l}\text { 作製条件 } \\
\text { 変更試料(3) }\end{array}$ & $\begin{array}{rr}\sigma_{11}: & 2.8 \pm 1.0 \\
\sigma_{22}: & 5.1 \pm 1.0 \\
\sigma_{12}: & -1.1 \pm 0.6\end{array}$ & 10-12 配向 \\
\hline
\end{tabular}

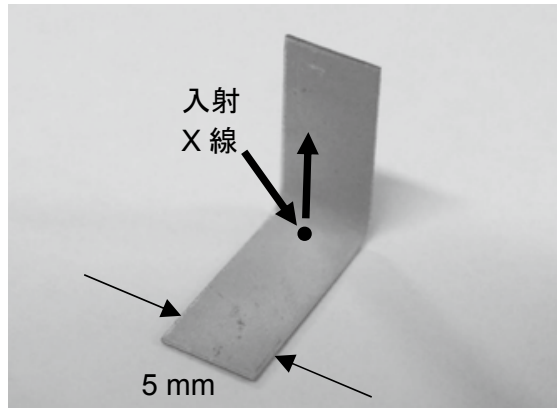

図 10 直角曲げ試料の微小部応力測定 
元検出器で測定する場合は多大な時間を要する。表 1 にある 作製条件変更試料(2)，(3)の直角曲げ試料を $\sin ^{2} \Psi$ 法により測 定した。表 1 の解析結果は $2 \mathrm{D}$ 応力法であるが, せん断応力 $\sigma_{12}$ の值が誤差の範囲内で $0 \mathrm{MPa}$ であれば $\sin ^{2} \Psi$ 法の值と比 較できる。解析の結果, 作製条件変更試料(2)では- $13.1 \pm$ $1.2 \mathrm{MPa}$, (3)では- $10.8 \pm 0.3 \mathrm{MPa}$ と算出され, 折り曲げの 影響により圧縮応力が増大していることが分かった。

\section{7. おわりに}

Zn めっき膜を試料として, 2 次元検出器を用いた極点図 測定・結晶方位解析, 残留応力測定, また 0 次元検出器と比 較しての長所・短所について解説した。2 次元検出器では, あおり方向の情報を含め, 露光方式で測定を行うことにより 測定している範囲の強度が同時に積算されるため, 0 次元検 出器に比べて大幅に測定時間を短縮することができる。しか し，全ての点において 2 次元検出器による測定が優れている
という訳ではなく，従来の 0 次元で測定したほうが質の高い データが得られる場合も多い。従って, 評価の目的に応じて, 0 次元と 2 次元による測定を使い分けることが重要である。

(Received August 28, 2015)

\section{文献}

1）土井 正, 水元和成, 青沼昌幸, 田中慎一; 表面技術, 53,335 (2002)

2）津留 豊,井上安幸, 高松亮太, 細川邦典; 表面技術, 45, 82 (1994).

3 ）井上晃一郎, 中田 毅, 渡辺 徽; 日本金属学会誌, 65,229 (2001).

4 ) H. J. Bunge ; Texture Analysis in Materials Science, Butterworths (1982).

5 ) J. -H. Cho, A. S. Rollett, K. H. Oh ; Metallurgical and Materials Transactions A, 35A, 1075 (2004).

6 ) M. Gelfi, E. Bontempo, R. Roberiti, L. E. Depero ; Acta Materialia, 52, 583 (2004). 